\title{
Nesting habitat selection of Mediterranean raptors in managed pinewoods: searching for common patterns to derive conservation recommendations
}

\author{
RAFAEL BARRIENTOS and BERNARDO ARROYO
}

\begin{abstract}
Summary
Investigating habitat selection is a key step in improving the population conservation of forest species in areas managed for different purposes, from timber harvesting to hunting or recreation. Because economic resources allocated to conservation are limited, studies that assess cost-effective strategies are necessary, especially when concerning non-threatened species. We studied nest-site habitat selection of two raptor communities (totalling 245 nests from the five most common species: Short-Toed Eagle Circaetus gallicus, Goshawk Accipiter gentilis, Sparrowhawk A. nisus, Common Buzzard Buteo buteo and Booted Eagle Aquila pennata) in two pinewoods in central Spain separated by $200 \mathrm{~km}$. Using a Generalised Linear Mixed Model for each species and with locality as a random factor, we obtained five models of habitat selection. We highlighted the common nesting patterns in order to facilitate an integrated management of forestry in relation to raptor nesting habitat selection. The most important variable for all species, with the exception of the Sparrowhawk was the nest-tree diameter at breast height, with raptors preferentially selecting nesting trees of large width. Tall trees and a high amount of tree cover around the nesting tree were also important habitat features for several species. Our results suggest that pinewoods should retain unharvested patches with moderate tree coverage $(30-70 \%)$ containing not only several large trees (diameter at breast height $>40 \mathrm{~cm}$ ) but also small ones. At the landscape level, open forests and heterogeneous habitats are preferred. These forest patches should be dispersed throughout the landscape.
\end{abstract}

\section{Introduction}

Management of forest habitats is typically complex, due to the variety of socioeconomic (timber harvesting, grazing, hunting, recreation) and environmental (biodiversity conservation, carbon sequestration, control of soil erosion) interests involved (Díaz-Balteiro and Romero 2008, Gustafsson et al. 2012). Guaranteeing the presence of top predators in present-day landscapes, which are dominated by humans, is a positive step toward ecosystem health (Linnell et al. 200o). Furthermore, the presence of top predators can entail benefits for ecosystem functionality, for instance, by providing resources to scavengers or initiating trophic cascades (Sergio et al. 2008).

Several human activities can constrain conservation of forest raptors, the top avian predators. One of such activities is timber harvesting, which results in the removal of trees in a manner markedly different from tree loss through natural processes such as fire or wind throw (Bengtsson et al. 2000). The forest harvesting regime and the resulting forest structure is a pivotal issue in the ecology and conservation of forest-dwelling species (Perhans et al. 2011, Kuuluvainen et al. 2012). 
Specifically for raptors, timber production may conflict with their conservation because large trees are the most valuable both for nesting raptors and the forest industry (Ewins 1997, Petty 1998). Furthermore, in their study of medium-sized raptors in a temperate forest, including the Goshawk, the Common Buzzard and the Honey Buzzard Pernis apivorus, Santangeli et al. (2012) found that a territory was less likely to be occupied if a clear-cut had occurred in the immediate vicinity of a nest and if a very small forest area was retained. Other works in temperate forests have found that raptors can tolerate moderate habitat deterioration within the nesting stand (Penteriani and Faivre 2001 for the Goshawk; Lõhmus 2005 for the same three species in addition to the Lesser Spotted Eagle Aquila pomarina and the Sparrowhawk). However, other studies in northern latitudes suggest that forestry can conflict with raptor conservation (Widén 1997 for the Goshawk, Kirk and Hyslop 1998 for several species) and can modify habitat selection patterns (Bielański 2006 for the Goshawk and Common Buzzard). Moreover, habitat alterations are often interrelated, as, for instance, timber exploitation not only decreases the size of mature (i.e. rotation-aged) stands, but also increases the road network in the forest (Widén 1997). Also, during sanitary cutting and thinning, trees with wide crowns or those with intensive lateral branch growth are usually removed or pruned, eliminating individual trees commonly selected for nesting by forest raptors (Bielański 2004).

As demonstrated by the abovementioned research, multi-species studies on nest-site habitat selection by raptors are relatively numerous in temperate forests (e.g. Kostrzewa 1996, Selas 1997, Krüger 2002a, Lõhmus 2005). However, similar works on Mediterranean raptors are not so common. This is important given that while some raptor species are distributed throughout Europe (for instance, the Goshawk, the Sparrowhawk or the Common Buzzard), other species are concentrated in the Mediterranean Basin (e.g. Short-Toed Eagle and Booted Eagle) (BirdLife International 2004). Studies carried out in Mediterranean areas usually focus on species-specific habitat requirements (Suárez et al. 2000, Bakaloudis et al. 2001, Bosch et al. 2005, Zuberogoitia et al. 2006), whereas multi-species approaches have only been conducted in a single study area in Greece (Poirazidis et al. 2007, 2011a). It is difficult to assess the congruence of habitat requirements across species, when the variables considered differ from one study to another. In contrast to previous work, we focused on the simultaneous study of nest-site habitat selection in five species of diurnal raptors from two Mediterranean pinewoods that differ in forest management, using the same methodology, statistics and variables for all species. Based on common nesting patterns, we aimed to identify general guidelines (i.e. those appropriate for most species, as opposed to speciesspecific management which implies more extensive conservation efforts) for pinewood management to benefit the Mediterranean raptor community as a whole, and to discuss the application of our conclusions to other areas where conservation is not the priority because: i) most widespread forest raptors usually show important overlap in habitat selection patterns (Krüger 2002a, Hakkarainen et al. 2004); ii) most Mediterranean forest raptors are in less threatened conservation categories (BirdLife International 2004); and iii) many nests are located in poorly protected pinewoods (in Mediterranean Spain, less than $7 \%$ of pinewoods are protected; Maldonado et al. 2001). The main advantage of our approach over those works that studied a single species is that by applying the same methodology for all five species in the two areas, the establishment of common rules is facilitated, improving implementation in areas with different forest structure and uses. Conservation approaches involving species-specific strategies is justified in cases of endangered species, many of which are already the target of species-specific action plans (see Burfield [2008] for European raptors). Furthermore, despite the fact that 'umbrella-species' (those species whose conservation is expected to confer protection to a large number of naturally co-occurring species; see Simberloff 1998, Branton and Richardson 2011) are commonly raptors (e.g. Sergio et al. 2006), a rigorous selection of candidate umbrella species and detailed knowledge of co-occurring species is required, but often lacking, as it is difficult to obtain (Simberloff 1998, Seddon and Leech 2008). Moreover, single umbrella species cannot ensure the conservation of all co-occurring species because different species are inevitably limited by different ecological factors that are not relevant to umbrella-species (Andelman and Fagan 2000, Roberge and Angelstam 2004, 
Roth and Weber 2008). Thus, despite the fact that their management may sometimes conflict (Simberloff 1998), multi-species approaches are an appealing alternative (Poirazidis et al. 2011a). These types of approaches are even more important when economic resources are limited. Indeed, the most cost-effective strategy maximises the level of conservation for a given cost (Ando et al. 1998). It is worth mentioning that management for conservation is difficult on privately-owned lands, where there may be greater emphasis on economic (as opposed to conservation) benefits (Mortimer 2008, Wikberg et al. 2009). Thus, easy-to-apply management tools are necessary to conserve biodiversity not only on reserves but also in managed forests or on private property (Carlén et al. 1999, Newburn et al. 2005, Mortimer 2008).

Our manuscript aims to identify common management targets for multiple raptor species because we expect: (i) important overlap among forest traits selected by different raptor species in Mediterranean habitats, similar to that found in temperate forests (Krüger 2002a, Hakkarainen et al. 2004); (ii) that small scale habitat features are the most important, as patches with large nest trees are key habitat traits elsewhere (Suárez et al. 2000, Penteriani 2002, Poirazidis et al. 2007); and (iii) that habitat selection may be influenced by the different management practices carried out in our two pinewoods, even though some authors found that certain practices do not affect nesting (Penteriani and Faivre 2001, Santangeli et al. 2012, but see also Widén 1997). To address these questions, we built five species-specific models with data from two raptor communities, one of them dwelling in a publicly managed forest (Alto Tajo), the other inhabiting a privately managed property (Quintos de Mora). This study design additionally allows us to evaluate whether habitat selection varies when raptors encounter different management practices (forestry vs. hunting). We identify the variables that should be taken into account when applying forest management practices that are meant to guarantee the conservation of the forest raptor community as a whole.

\section{Methods}

\section{Study species}

The group of raptors that we studied (Table 1 ) includes the five most widespread species out of twelve primarily tree-nesting species that breed in the Iberian Peninsula (Martí and del Moral 2004), species that are also abundant in other Mediterranean forests areas (e.g. Poirazidis et al. $2011 \mathrm{~b})$. The nests from the study species represent $96 \%$ of the total raptor nests found in the study areas. We excluded three Black Kite Milvus migrans nests and one European Hobby Falco subbuteo nest in Alto Tajo, and five Cinereous Vulture Aegypius monachus and two Spanish Imperial Eagle Aquila adalberti nests in Quintos de Mora due to their low populations in the study areas. Furthermore, the two latter species are in unfavourable conservation status (BirdLife International 2013) and species-specific management is likely justified in their case, which includes not only forest management but also nest vigilance or supplementary feeding (González et al. 2006a, b, Margalida et al. 2011). The Honey Buzzard, the Black-Shouldered Kite Elanus caeruleus and the Red Kite M. milvus do not breed in our study areas or do so at very low densities (Martí and del Moral 2004).

\section{Study areas}

The Alto Tajo Natural Park (central Spain, $40^{\circ} 45^{\prime} \mathrm{N}, 2^{\circ} 10^{\prime} \mathrm{W}$ ) occupies a mountainous area of 177,433 ha, ranging from 760 to $1,880 \mathrm{~m}$ asl, characterized by limestone plains crossed by deep river canyons. The climate is Mediterranean-continental with $500 \mathrm{~mm}$ of year-round rainfall. Vegetation is dominated by pinewoods managed for timber, accounting for $56 \%$ of the land surface area. The tree species in these woods include Iberian Scots pine Pinus sylvestris, maritime pine $P$. pinaster, black pine P. nigra and Aleppo pine P. halepensis. Due to forestry, other autochthonous stands, like those dominated by oaks (holm Quercus ilex, Pyrenean Q. pyrenaica or Portuguese Q. faginea), are underrepresented and trees reach smaller sizes (Barrientos and Bolonio 2003). 
Table 1 . Number of studied nests by species in each study area. Conservation status is based on BirdLife International (2004) criteria, with SPEC 3: species with global populations not concentrated in Europe but of unfavourable conservation status in Europe; and, Non-SPEC: species with global populations not concentrated in Europe and of favourable conservation status in Europe.

\begin{tabular}{lllllll}
\hline Study area / Species & \multicolumn{1}{l}{ Short-toed Eagle } & Goshawk & \multicolumn{1}{l}{ Sparrowhawk } & Common Buzzard & Booted Eagle & Total \\
\hline Alto Tajo & 5 & 46 & 11 & 25 & 58 & 145 \\
Quintos de Mora & 11 & 21 & 18 & 12 & 38 & 100 \\
Conservation status 2004 & SPEC $_{3}$ & Non-SPEC & Non-SPEC & Non-SPEC & SPEC $_{3}$ & 245 \\
\hline
\end{tabular}

The management system is clear-cutting, where trees are extracted in four progressive steps of $25 \%$ felling each. The time between the first thinning and the final felling is about $100-120$ years. The area is made up of $12 \%$ of Spanish juniper Juniperus thuriphera forests and $12 \%$ of scrubland, including several species (Genista spp., Cytisus spp., Erica spp. and Cistus albidus). The majority of the study area is publically owned, and heavily used for recreation (including trekking, swimming, off-road use, and hunting) by the general public.

Despite the fact that Quintos de Mora $\left(39^{\circ} 24^{\prime} \mathrm{N}, 4^{\circ} 3^{\prime} \mathrm{W} ; 6,864\right.$ ha, located more than $200 \mathrm{~km}$ south-west of Alto Tajo) is a government-owned property, it is managed similarly to the private properties that are common in the midlands of the Iberian Peninsula, especially in the centralwestern region. The whole area is fenced and entrance is forbidden to the general public, as it is dedicated to game hunting, especially of the red deer Cervus elaphus and the wild boar Sus scrofa. Other activities allowed in public forests, such as grazing and recreation, are not allowed at Quintos de Mora. Thus, we used this study area as a surrogate for private property. It is dominated by two main biotopes, the hills and the valley located between them. The climate is Mediterranean with $650 \mathrm{~mm}$ of year-round rainfall. The mountains reach up to $1,200 \mathrm{~m}$, their vegetation comprises an overstorey dominated by holm and Portuguese oaks and a shrub layer dominated by Arbutus unedo, C. ladanifer and Erica spp. (Barrientos 2010). In the wet gullies, other tree species such as Pyrenean and cork oaks $Q$. suber are present. The main valley between the two mountain ranges lies at $800 \mathrm{~m}$ and is dominated by dehesas, a savannah-like habitat widespread throughout southwestern Spain and characterised by the presence of scattered trees distributed across a pasturedominated matrix. The main tree species in dehesas are usually holm, Portuguese or cork oaks, but at Quintos, the first two species alternate with stone pines P. pinea and arable crops grown as food for game species. Conifers are present at Quintos because one-third of the property was planted with maritime and stone pines in the fifties, mainly in the valley, but also on the lower slopes of the hills (Barrientos 2010). After decades without felling, during the last five years entire areas of pinewoods are being clear-cut to allow original vegetation recovery.

\section{Data collection}

A total of 145 nests were studied at Alto Tajo during the 2001 and 2004 breeding seasons and 100 at Quintos de Mora between 2001 and 2008 (Table I), when nests were systematically searched for. Unfortunately, due to the large size of Alto Tajo Natural Park, the census was incomplete, and thus we could not include in our analyses variables such as pair density or distance to the nearest neighbour. Some species (especially Common Buzzard and Booted Eagle) commonly reuse nests built by other species of similar size, but we took into account only the raptor species that built each nest, and not the successive breeders, if any, and discarded all nests built by unknown species. This caution is necessary as those pairs reusing an old nest may choose the patch due to the presence of the nest, thus biasing habitat selection (Hakkarainen et al. 2004, Prokop 2004). Habitat measurements were taken only once at each nest in Alto Tajo and Quintos de Mora in 2004 and 2008, respectively, and were used only once in analyses to avoid pseudoreplication. Nests that underwent any habitat change (e.g., building of new tracks or plot logging) before we conducted the habitat measurement were removed from the dataset. In a few cases $(5 \%)$, 
we included up to three nests from a potential single territory, because territory shifts were difficult to monitor as birds were not marked. Although this may lead to some sampling biases, the use of long-term datasets minimises such biases, as they exceed the lifespan of most raptor species (see Krüger 2002a). Nest locations were recorded with a Garmin GPS eTrex Summit receiver (Garmin International, Olathe, KS) and incorporated into a Geographical Information System (GIS). As our aim was to analyse the effects of forest structure on raptor habitat selection, we did not include other factors that can affect the location of raptor nests such as intra- or interspecific competition or predator/prey abundances. Once the breeding season ended, we measured 21 habitat variables (Table 2). We considered the variables that have been reported as relevant in previous studies on forest raptor habitat selection including HEIGHT, DBH and TRACK to describe nest-tree traits and DBH- 3 and DIST- 3 to describe the characteristics of the three nearest trees in a $17.8 \mathrm{~m}$ radius, a measure applied in other multi-species studies (Selas 1997, Poirazidis et al. 2007). Also the nesting microhabitat (BUSH, TREE, DBH < 30 and DBH $>30$ ) was described using circular plots of $17.8 \mathrm{~m}$ radius around the nest-tree (Selas 1997; Poirazidis et al. 2007). The trees were counted and the coverage was visually estimated in $10 \%$ increments (0-10\%, 10-20\% and so on). Finally, we described the nesting landscape with the coverage of land uses in circular plots with radii of 500 and 1,500 m (similar to those employed by Suárez et al. 2000, Krüger 2002a,b, Bosch et al. 2005) using the variables freely available from the Second National Forest Inventory (SNFI) from 1995 (MAMR 1995). We are aware that raptor home ranges can exceed the area considered here (Kenward et al. 2001, Martínez et al. 2007). However, larger habitats are difficult to manage at a local scale as they require regional approaches (e.g. Carrete and Donázar 2005), which falls outside of the aims of the present study. The category "artificial unproductive" computed in the SNFI was used only to assess the number of habitat classes, and was not included as a variable in the modelling as this category was very scarcely represented (mean $<0.4 \%$ ) in our study areas. We used GIS to assess the proportion of the different habitat uses, the length of ecotones (also freely available from the SNFI and computed as the length of borders between patches with different land uses) and the number of habitat classes. We used Quantum GIS v. 1.7.4 to overlay the plot of nests onto the digitised habitat map from the SNFI to calculate the land use

Table 2. The variables measured to study the factors that differentiate nest trees from random ones.

\begin{tabular}{|c|c|c|}
\hline Variable & Definition & Data origin \\
\hline HEIGHT & Tree height $(\mathrm{cm})$ of the focal tree & Field \\
\hline $\mathrm{DBH}$ & Diameter $(\mathrm{cm})$ at breast height $(\mathrm{DBH})$ of the focal tree & Field \\
\hline TRACK & Distance $(\mathrm{m})$ from the focal tree to the nearest track & GIS \\
\hline $\mathrm{DBH}-3$ & Mean DBH $(\mathrm{cm})$ of the 3 nearest trees to the focal tree & Field \\
\hline DIST-3 & Mean distance $(\mathrm{m})$ of the 3 nearest trees to the focal tree & Field \\
\hline BUSH & Percentage (visually estimated) bush cover for a $17.8 \mathrm{~m}$ radius & Field \\
\hline TREE & Percentage (visually estimated) tree cover for a $17.8 \mathrm{~m}$ radius & Field \\
\hline $\mathrm{DBH}<30$ & Number (counted) of trees with $\mathrm{DBH}<3 \mathrm{Ocm}$ in a $17.8 \mathrm{~m}$ radius & Field \\
\hline $\mathrm{DBH}>30$ & Number (counted) of trees with $\mathrm{DBH}>30 \mathrm{~cm}$ in a $17.8 \mathrm{~m}$ radius & Field \\
\hline FORE $>20 \_500$ & Percentage of forest habitat where trees cover $>20 \%$ for a $500 \mathrm{~m}$ radius & GIS \\
\hline FORE 5-20_5OO & Percentage forest habitat where trees cover $5-20 \%$ for a $500 \mathrm{~m}$ radius & GIS \\
\hline $\mathrm{FORE}<5-500$ & Percentage forest habitat where trees cover $<5 \%$ for a $500 \mathrm{~m}$ radius & GIS \\
\hline CULT_5OO & Percentage cultivated field or grassland cover for a $500 \mathrm{~m}$ radius & GIS \\
\hline $\mathrm{ECOT}_{-500}$ & Length $(\mathrm{m})$ of ecotones among the different habitat classes for a $500 \mathrm{~m}$ radius & GIS \\
\hline CLAS_500 & Number of habitat classes $(1-5)$ for a $500 \mathrm{~m}$ radius & GIS \\
\hline FORE>20_1500 & Percentage forest habitat where trees cover $>20 \%$ for a $1,500 \mathrm{~m}$ radius & GIS \\
\hline FORE 5-20_15OO & Percentage of forest habitat where trees cover $5-20 \%$ for a $1,500 \mathrm{~m}$ radius & GIS \\
\hline FORE $<5 \_1500$ & Percentage of forest habitat where trees cover $<5 \%$ for a $1,500 \mathrm{~m}$ radius & GIS \\
\hline CULT_1500 & Percentage cultivated field or grassland cover for a $1,500 \mathrm{~m}$ radius & GIS \\
\hline ECOT_I500 & Length $(\mathrm{m})$ of ecotones among the different habitat classes for a $1,500 \mathrm{~m}$ radius & GIS \\
\hline CLAS_1500 & Number of habitat classes $(1-5)$ for a $1,500 \mathrm{~m}$ radius & GIS \\
\hline
\end{tabular}


cover around nests. We used the distance to the nearest forest track as a surrogate of human disturbance because our study areas have low stable human populations $(<<1$ inhabitant/ha) but potentially high numbers of visitors due to hikers or forest workers (see also González et al. 2006a, Margalida et al. 2011).

Habitat selection studies require the comparison of the nest sites with a randomly chosen control set of unused sites (Manly et al. 1993). Thus, 90 trees with their corresponding forest plots were randomly measured both at Alto Tajo, in 2004, and at Quintos de Mora, in 2008. Following Bakaloudis et al. (2001), random trees were situated $<400 \mathrm{~m}$ from the nearest nest-tree in order to avoid overlap with the nest-tree habitats at a small scale and to guarantee its representativeness within the study area; that is, to avoid the placement of random points outside of the forest. Potential random trees outside of forest patches (e.g. isolated in cultivated fields or grasslands) were discarded, as forest raptors do not nest there. For this reason, we used this procedure instead of pure random selection. We used 30 random trees from each study area for the Short-Toed Eagle, Sparrowhawk and Common Buzzard models and 60 for the Goshawk and Booted Eagle to balance the number of nests with the number of random points in each species.

\section{Statistical analyses}

We evaluated quantitative differences between the characteristics of nest-trees of each species and random trees in both studied areas using unpaired $t$-tests and applying the Bonferroni stepdown correction (Holm 1979). Previously, variables measuring the percentage of the circle area were arcsine square root-transformed as appropriate. Tests were calculated using STATISTICA 7.o. Additionally, we used multivariate approaches, which are preferable to univariate given that correlations among variables may mask direct effects (Lõhmus 2005). We used a principal component analysis (PCA) with varimax normalised factor rotation to build a correlation matrix to explore the degree of association among the 21 variables for every species. For subsequent model development, and in order to minimise multicollinearity among independent variables, we only included the variable most highly correlated with each of the principal component (PC) factors, discarding the remaining variables with correlations $>0.6$ (Tables $\mathrm{S}_{1}-\mathrm{S}_{5}$ in the online supplementary material). This technique allows the direct use of original variables rather than PCA factors, which are sometimes difficult to interpret from an ecological point of view. To evaluate which parameters affect nest-site habitat selection, generalised linear mixed models (GLMM) were fitted for each species with a binomial error distribution (nest-trees $v$ s. random trees). The variable 'study area' (Alto Tajo vs. Quintos de Mora) was set up as a random factor. Our design, including locality as a random factor entails the random factor taking part of the degrees of freedom. Thus the effect sizes of our variables have to be higher to get significant results. In other words, our conclusions are conservative and stronger as we remove potential locality-related effects. By applying Akaike Information Criterion (AIC), parsimonious models were achieved by removing the variables with the lowest explanatory power and retaining the model that maximised the explained deviance (Burnham and Anderson 2002). The GLMMs were fitted using R 2.II.1 statistical software (R Development Core Team 2009; Imer in lme4 library).

\section{Results}

\section{General overview}

Nests were exclusively located on pines at Alto Tajo $(n=145)$ and on pines $(92 \%)$ and on oaks $(8 \%)$ at Quintos de Mora $(n=100)$. General habitat (i.e. random points) was markedly different between our two study areas as Alto Tajo trees were taller $(t=4.3, P<0.01)$ and thicker $(t=10.4$, $P<0.001)$, and density of trees within the $17.8 \mathrm{~m}$ radius was higher $(\mathrm{DBH}<30: t=4.6, P<0.001$; $\mathrm{DBH}>30: t=17.0, P<0.001$; see also Table S6). On the contrary, the crown coverage within that radius was higher at Quintos de Mora $(t=-8.6, P<$ o.oo1 $)$. The track net was more developed at 
Quintos de Mora as shown by the shorter distance of random trees to the nearest track $(t=3.6$, $P<0.01$ ). Alto Tajo had more forest coverage (FORE $>20 \_500, t=3.8, P<0.01$; FORE $>20 \_1500$, $t=4.3, P<0.001$ ) and this was more heterogeneous, as ecotone length was greater at both scales considered (ECOT_500, $t=5.4, P<0.001$; ECOT_1500, $t=6.7, P<0.001$; see also Table S6).

\section{Patterns of habitat selection}

The five studied raptors showed several common patterns of nest habitat selection. First, the variable 'study area' was not statistically significant in any model. In all the models, except for the Sparrowhawk, DBH was the most important variable (Table 4) with raptors selecting trees larger than the mean size of available trees (Table 3 and Figure S6). HEIGHT - another measurement of tree size - was also a significant variable in the Common Buzzard and the Booted Eagle models (Table 4) with raptors selecting taller trees (Table 3 and Figure S6). Also, a significant variable for the Goshawk, the Sparrowhawk and the Booted Eagle was TREE (Table 4) with these species selecting patches with greater tree cover (Table 3 and Figure S6).

The remaining statistically significant variables included in the models were retained only for one species and the interpretation was not always straightforward, mostly showing nonsignificant trends. Interestingly, the variables related to greatest forest cover at both landscape scales (FORE $>20 \_500$ and FORE $>20 \_1500$ ) were not significant in any of the five models.

Explained deviance was $30.9 \%$ for the Short-Toed Eagle, $26.8 \%$ for the Goshawk, $21.7 \%$ for the Sparrowhawk, $38.9 \%$ for the Common Buzzard and $27.8 \%$ for the Booted Eagle.

\section{Discussion}

Several variables differed between random and nest trees for the five studied species. Variables selected at smaller scales (tree-scale and $17.8 \mathrm{~m}$ radius) are related to nest-tree habitat selection, and were, in general, the most important in all the models. On the contrary, those variables selected at larger scales (500 and 1,500 radii) were less important in nest-site selection. It is interesting that study area (forest management regime) was not important for nesting habitat selection, implying that forest-related variables found to be important were the same in both pinewoods. In other words, our results can be applied to raptor conservation in relation to forestry in other Mediterranean pinewoods.

Regarding the common patterns in nest-site habitat selection, it is worth noting that the most important variable was size, expressed as diameter at breast height (DBH) or tree height, of the tree selected for nesting, as raptors nested in trees larger than the mean available. Raptors select

Table 3. Statistically significant variables in the analyses of habitat selection when comparing random points with the placement of the nests of every species in both study areas. Asterisks mark the significance levels as follows: ${ }^{*}=P<0.05 ;^{* *}=P<0.01{ }^{* * *}=P<0.001$, with 'NS' being non-significant. See Table 1 for sample sizes, Table 2 for variable definitions and Figure S6 for the complete list of figures.

\begin{tabular}{|c|c|c|c|c|c|c|c|c|c|c|}
\hline \multirow[b]{2}{*}{ Variable } & \multicolumn{2}{|c|}{ Short-toed Eagle } & \multicolumn{2}{|l|}{ Goshawk } & \multicolumn{2}{|c|}{ Sparrowhawk } & \multicolumn{2}{|c|}{ Common Buzzard } & \multicolumn{2}{|c|}{ Booted Eagle } \\
\hline & Alto Tajo & Quintos & Alto Tajo & Quintos & Alto Tajo & Quintos & Alto Tajo & Quintos & Alto Tajo & Quintos \\
\hline HEIGHT & NS & * & ** & $* * *$ & NS & NS & NS & * & NS & $* * *$ \\
\hline $\mathrm{DBH}$ & NS & $* * *$ & NS & $* * *$ & NS & NS & * & $* * *$ & * & $* * *$ \\
\hline $\mathrm{DBH}-3$ & NS & NS & NS & NS & NS & NS & NS & $* *$ & NS & NS \\
\hline DIST-3 & NS & NS & $* *$ & NS & NS & NS & NS & NS & NS & NS \\
\hline$\%$ BUSH & NS & $* *$ & NS & NS & NS & NS & NS & NS & NS & NS \\
\hline \% TREE & NS & NS & $*$ & $* * *$ & NS & NS & NS & NS & NS & NS \\
\hline $\mathrm{DBH}<30$ & NS & NS & $*$ & NS & NS & NS & NS & NS & $*$ & NS \\
\hline $\mathrm{DBH}>30$ & NS & NS & NS & $* * *$ & NS & NS & $*$ & $*$ & NS & $* *$ \\
\hline CULT_1500 & NS & NS & NS & NS & $*$ & NS & * & NS & $* *$ & NS \\
\hline
\end{tabular}


Table 4. Results for species-specific GLMM analyses with the study area (Alto Tajo vs. Quintos de Mora) as a random factor.

\begin{tabular}{|c|c|c|c|c|}
\hline \multicolumn{5}{|l|}{ Short-toed Eagle } \\
\hline & Estimate & SE & $\mathrm{z}$ & $P$ \\
\hline Intercept & -9.8640 & 2.6105 & -3.78 & 0.0002 \\
\hline $\mathrm{DBH}$ & 0.1440 & 0.0434 & $3 \cdot 32$ & 0.0009 \\
\hline BUSH & 0.0499 & 0.0199 & 2.51 & 0.0123 \\
\hline $\mathrm{DBH}<30$ & 0.0215 & 0.0082 & 2.61 & 0.0090 \\
\hline FORE<5_15OO & -0.0186 & 0.0163 & -1.14 & 0.2545 \\
\hline \multicolumn{5}{|l|}{ Goshawk } \\
\hline & Estimate & SE & $\mathrm{z}$ & $P$ \\
\hline Intercept & 5.649 & 1.5939 & -3.54 & 0.0004 \\
\hline $\mathrm{DBH}$ & 0.096 & 0.0210 & 4.57 & $<0.0001$ \\
\hline $\mathrm{DBH}-3$ & -0.033 & 0.0209 & -1.58 & 0.1147 \\
\hline DIST-3 & -0.159 & 0.1365 & -1.17 & 0.2434 \\
\hline TREE & 0.060 & 0.0143 & 4.25 & $<0.0001$ \\
\hline \multicolumn{5}{|l|}{ Sparrowhawk } \\
\hline & Estimate & $\mathrm{SE}$ & $\mathrm{z}$ & $P$ \\
\hline Intercept & -6.7058 & 1.6957 & -3.96 & $<0.0001$ \\
\hline TREE & 0.0451 & 0.0137 & $3 \cdot 30$ & 0.0010 \\
\hline $\mathrm{DBH}<30$ & 0.0078 & 0.0051 & 1.51 & 0.1302 \\
\hline FORE 5-20_15OO & -0.0122 & 0.0106 & -1.15 & 0.2515 \\
\hline FORE $<5 \_1500$ & -0.0318 & 0.0164 & -1.93 & 0.0532 \\
\hline CLAS_1500 & 1.0861 & 0.3672 & 2.96 & 0.0031 \\
\hline \multicolumn{5}{|l|}{ Common Buzzard } \\
\hline & Estimate & SE & $\mathrm{z}$ & $P$ \\
\hline Intercept & -9.9840 & 2.2539 & -4.43 & $<0.0001$ \\
\hline HEIGHT & 0.0022 & 0.0010 & 2.13 & 0.0336 \\
\hline $\mathrm{DBH}$ & 0.1372 & 0.0358 & 3.83 & 0.0001 \\
\hline BUSH & 0.0180 & 0.0185 & 0.97 & 0.3316 \\
\hline TREE & 0.0236 & 0.0167 & 1.42 & 0.1568 \\
\hline $\mathrm{DBH}<30$ & 0.0101 & 0.0057 & 1.78 & $0.075^{1}$ \\
\hline $\mathrm{DBH}>30$ & -0.0266 & 0.0148 & -1.79 & 0.0735 \\
\hline FORE $<5-500$ & -0.0281 & 0.0146 & -1.92 & 0.0555 \\
\hline CULT_5OO & 0.0475 & 0.0159 & 2.98 & 0.0029 \\
\hline \multicolumn{5}{|l|}{ Booted Eagle } \\
\hline & Estimate & $\mathrm{SE}$ & $\mathrm{z}$ & $P$ \\
\hline Intercept & -6.8270 & 1.1480 & -5.95 & $<0.0001$ \\
\hline HEIGHT & 0.0001 & 0.0000 & 2.70 & 0.0069 \\
\hline $\mathrm{DBH}$ & 0.0079 & 0.0017 & $4 \cdot 54$ & $<0.0001$ \\
\hline TREE & 0.0027 & 0.0009 & 2.78 & 0.0055 \\
\hline $\mathrm{DBH}<30$ & 0.0005 & 0.0002 & 1.95 & 0.0510 \\
\hline FORE $5-20 \_500$ & -0.0054 & 0.0007 & -1.99 & 0.0468 \\
\hline $\mathrm{ECOT}_{-500}$ & -0.0000 & 0.0000 & -2.65 & 0.0081 \\
\hline FORE $<5 \_1500$ & 0.0023 & 0.0011 & 2.11 & 0.0345 \\
\hline ECOT_1500 & 0.0000 & 0.0000 & 1.51 & 0.1324 \\
\hline
\end{tabular}

these trees because they provide more stable nest support (Newton 1979, Penteriani 2002), as well as protection against predators and other sources of disturbance (Moreno-Opo et al. 2012). This trend was similar for the five species and in the two localities, except for the Sparrowhawk in Alto Tajo. This species is the smallest of the five (del Hoyo et al. 1994), and trees of the mean size in Alto Tajo are likely sufficient to guarantee stability for the smaller Sparrowhawk nests. In fact, 
the Sparrowhawk's preference for young, dense stands has been previously reported (Selås 1997, Lõhmus 2005). Tree cover around the nest was another important variable for most species. Dense stands are important in order to reduce predation or exposure to bad weather (Selås 1997, Penteriani and Faivre 2001, Krüger 2002a). This variable seemed to be particularly important for the two Accipiter species.

The rest of the significant variables were species-specific. The importance of moderate (c. $25-50 \%$ ) bush cover around nest trees in the Short-Toed eagle is likely related to the existence of open forest plots, where this species usually nests (Bakaloudis et al. 2001). Whereas the number of trees with DBH $<30 \mathrm{~cm}$ for a $17.8 \mathrm{~m}$ radius was higher than average in the Goshawk and the Booted Eagle nest plots in Alto Tajo, this variable showed different trends in the two study areas for the Short-Toed Eagle. The density of trees around the nest contributes to hiding the nest from predators. The different trends found could be related to the type and density of predators present in each area, as locality-related differences in habitat selection by nesting birds can be related to the different nest predator assemblages present in a given area (e.g. Martin and Joron 2003, Barrientos et al. 2009). However, we have no information on predator densities to confirm this relationship (see below).

The variables included in some models at 500 and 1,500 m radii were related to ecotone length, habitat class richness and cultivation cover, whereas variables related to the greatest forest cover were not significant. Thus, these results highlight the importance of moderately forested areas and, more importantly, of heterogeneous habitats. Habitat mosaics like open woodlands combined with large agroforestry landscapes are key habitats for Mediterranean forest raptors (SánchezZapata and Calvo 1999). The use of open habitats such as farmland or scrubland seems to be mediated by the importance of reptiles and edge-nesting birds in the diets of species like the Short-Toed and the Booted Eagle (Bakaloudis et al. 1998, Martínez et al. 2007, Moreno-Rueda and Pizarro 2007, Bakaloudis 2009). A moderate proportion of crops (c.20\%) alternated with forested areas was selected by the Common Buzzard in our study as these mosaic habitats are adequate both for nesting and foraging (Butet et al. 2010). However, our results must be considered with caution, as raptor home ranges are larger than the surface area studied here, even with our larger radii. For instance, Goshawks have ranges of 670 ha on average in Sweden (Kenward et al. 2001) and Booted Eagles up to 9,000-23,000 ha in Spain (Martínez et al. 2007). Furthermore, as we have no data on prey availability, we cannot evaluate its importance on nesting habitat selection (see below).

Finally, it is worth noting that most of the deviance remained unexplained (c.6o-80\%) with our forestry-related variables. This could be due to the fact that the studied species are forest generalists, present in a wide range of habitats (del Hoyo et al. 1994), consequently making their habitat requirements more difficult to model. It is also plausible that other factors, often interrelated, and not considered in our analyses, could have played important roles in determining the settlement of nesting pairs. First, the set of predators present could have influenced our results, as avoiding predation is important for habitat selection (Selås 1997). Second, the availability of prey within a certain territory can also be important in territory occupation (Widén 1997). Third, previous occupancy and reproductive outputs have a strong influence on subsequent territory occupation (Krüger 2002b, Martínez et al. 2006). Fourth, intraspecific interactions can influence nesting location, as territories of lower quality are occupied only in years of higher density of breeding pairs (Krüger and Lindström 2001). On the contrary, other authors have found that some raptors seem to select nesting patches close to conspecifics (Martínez et al. 2006). Finally, interspecific competition may be also important (but see Jiménez-Franco et al. 2011). Thus, Krüger (2002a) suggested that habitat preferences in some raptors might be based on avoidance of dominant species, rather than on landscape traits, with territory occupancy being dependent on the presence of competitors (Hakkarainen et al. 2004).

To summarise, our work is the first that uses the same methodology to study five of the most common medium-sized raptors dwelling in western Mediterranean pinewoods in relation to forest management variables. Our multi-species approach loses specificity, but gains in applicability. Nest-site habitat selection patterns were similar in our two study areas and mirror those found in species-specific studies, stressing the importance of patches with large trees in guaranteeing the 
establishment of breeding pairs. Future research could include an evaluation of the importance of territory quality (presence of competitors, prey abundance) and how this influences fledgling productivity.

\section{Conservation implications}

In the present work, we highlight the common nesting patterns for two communities of Mediterranean forest raptors made up of the same five species. We avoid species-specific recommendations in order to facilitate an integrated management. To guarantee forest raptor nesting in managed pinewoods, our results suggest that woodcutters should leave unharvested patches with moderate tree coverage (roughly, 30-70\%) containing not only several large trees (DBH > $40 \mathrm{~cm}$ ) but also small ones. These patches should be at least 0.1 ha in size, although further research is needed to define that size more accurately. At the landscape level, moderately forested (as opposed to continuous, dense forests) and heterogeneous habitats, including non-forest patches, are preferred. Consequently, mature forest patches should be dispersed throughout the landscape. Following the aforementioned guidelines, forest planners or owners can contribute to the identification of suitable patches for retention in unprotected areas. These practices should guarantee suitable nesting conditions for the most common raptors dwelling in Mediterranean habitats, with species-specific measures only required when threatened species are present.

\section{Supplementary Material}

The supplementary materials referred to in this article can be found at journals.cambridge.org/bci

\section{Acknowledgements}

We thank R. Ruiz, A. Vela, E. Fuertes and D. López for their support at Alto Tajo and J. M. Sebastián, C. Rodríguez-Vigal, C. López, A. Ancos and J. Polo at Quintos de Mora. This work was promoted and funded by the Alto Tajo Natural Park-Junta de Comunidades de Castilla-La Mancha and the Organismo Autónomo de Parques Nacionales. We are indebted to A. Torres, C. Ponce and E. Virgós for helping with GLMM procedures and to G. Moreno-Rueda, A. Margalida and three anonymous reviewers for their suggestions on a first draft. S. Young checked the English.

\section{References}

Andelman, S. J. and Fagan, W. F. (2000) Umbrellas and flagships: Efficient conservation surrogates or expensive mistakes? Proc. Natl. Acad. Sci. USA 97: 5954-5959.

Ando, A., Camm, J. and Polasky, A. S. (1998) Species distribution, land values, and efficient conservation. Science 279: 2126-2128.

Bakaloudis, D. E. (2009) Implications for conservation of foraging sites selected by Shorttoed Eagles (Circaetus gallicus) in Greece. Ornis. Fenn. 86: 89-96.

Bakaloudis, D. E., Vlachos, C. G. and Holloway, G. J. (1998) Habitat use by short-toed eagles Circaetus gallicus and their reptilian prey during the breeding season in Dadia Forest (north-eastern Greece). J. Appl. Ecol. 35: $821-828$.
Bakaloudis, D. E., Vlachos, C., Papageorgiou, N. and Holloway, G. J. (200I) Nest-site habitat selected by Short-toed Eagles Circaetus gallicus in Dadia Forest (northeastern Greece). Ibis 143: 391-401.

Barrientos, R. (2010) Retention of native vegetation within the plantation matrix improves its conservation value for a generalist woodpecker. For. Ecol. Manage. 260: 595-602.

Barrientos, R. and Bolonio, L. (2003) Selección del microhábitat de alimentación por el pico picapinos Dendrocopos major en un pinar de España central. Ardeola 50: 269-274.

Barrientos, R., Valera, F., Barbosa, A., Carrillo, C. M. and Moreno, E. (2009) Plasticity of nest site selection in the trumpeter 
finch: a comparison between two habitats. Acta Oecol. 35: 499-506.

Bengtsson, J., Nilsson, S. G., Franc, A. and Menozzi, P. (2000) Biodiversity, disturbances, ecosystem function and management of European forests. For. Ecol. Manage. 132: 39-50.

Bielański, W. (2004) Impact of common silvicultural treatments on nest tree accessibility for Common Buzzard Buteo buteo and Goshawk Accipiter gentilis. Ornis. Fenn. 81: 180-185.

Bielański, W. (2006) Nesting preferences of common buzzard Buteo buteo and goshawk Accipiter gentilis in forest stands of different structure (Niepolomice Forest, Southern Poland). Biologia 61: 597-603.

BirdLife International (2004) Birds in Europe: Population estimates, trends and conservation status. Cambridge, UK: BirdLife International.

BirdLife International (2013) IUCN Red List for birds. http://www.birdlife.org. Last accessed: 31/03/2013

Bosch, J., Borrás, A. and Freixas, J. (2005) Nesting habitat selection of booted eagle Hieraaetus pennatus in central Catalonia. Ardeola 52: 225-233.

Branton, M. and Richardson, J. S. (2011) Assessing the value of the umbrella-species concept for conservation planning with metaanalysis. Conserv. Biol. 25: 9-20.

Burfield, I. J. (2008) The conservation status and trends of raptors and owls in Europe. Ambio 37: 401-407.

Burnham, K. P. and Anderson, D. R. (2002) Model selection and multimodel inference. New York, USA: Springer.

Butet, A., Michel, N., Rantier, Y., Comor, V., Hubert-Moy, L., Nabucet, J. and Delettre, Y. (2010) Responses of common buzzard (Buteo buteo) and Eurasian kestrel (Falco tinnunculus) to land use changes in agricultural landscapes of Western France. Agric. Ecosyst. Environ. 138: 152-159.

Carlén, O., Mattsson, L., Atlegrim, O. and Sjöberg, K. (1999) Cost efficiency in pursuing environmental objectives in forestry. J. Environ. Manage. 55: 111-125.

Carrete, M. and Donázar, J. A. (2005) Application of central-place foraging theory shows the importance of Mediterranean dehesas for the conservation of the cinereous vulture,
Aegypius monachus. Biol. Conserv. 126: 582-590.

del Hoyo, J., Elliott, A. and Sargatal, J., eds. (1994) Handbook of the birds of the world. Vol. 2. New World vultures to guineafowl. Barcelona, Spain: Lynx Edicions.

Díaz-Balteiro, L. and Romero, C. (2008) Making forestry decisions with multiple criteria: A review and an assessment. For. Ecol. Manage. 255: 3222-3241.

Ewins, P. J. (1997) Osprey (Pandion haliaetus) populations in forested areas of North America: changes, their causes and management recommendations. J. Raptor Res. 31: 138-150.

González, L. M., Arroyo, B. E., Margalida, A., Sánchez, R. and Oria, J. (2006a) Effect of human activities on the behaviour of breeding Spanish imperial eagles (Aquila adalberti): management implications for the conservation of threatened species. Anim. Conserv. 9: 85-93.

González, L. M., Margalida, A., Sánchez, R. and Oria, J. (2006b) Supplementary feeding as an effective tool for improving breeding success in the Spanish imperial eagle (Aquila adalberti). Biol. Conserv. 129: 477-486.

Gustafsson, L., Baker, S. C., Bauhus, J., Beese, W. J., Brodie, A., Kouki, J., Lindenmayer, D. B., Lohmus, A., Pastur, G. M., Messier, C., Neyland, M., Palik, B., Svedrup-Thygeson, A., Volney, W. J. A., Waynes, A. and Franklin, J. F. (2012) Retention forestry to maintain multifunctional forests: a world perspective. Bioscience 62: 633-645.

Hakkarainen, H., Mykrä, S., Kurki, S., Tornberg, R. and Jungell, S. (2004) Competitive interactions among raptors in boreal forests. Oecologia 141: 420-424.

Holm, S. (1979) A simple sequentially rejective Bonferroni test procedure. Scand. J. Stat. 6 : 65-70.

Jiménez-Franco, M. V., Martínez, J. E. and Calvo, J. F. (2011) Territorial occupancy dynamics in a forest raptor community. Oecologia 166: 507-516.

Kenward, R. E., Clarke, R. T., Hodder, K. H. and Walls, S. N. (2001) Density and linkage estimators of home range: nearest-neighbor clustering defines multinuclear cores. Ecology 82: 1905-1920. 
Kirk, D. A. and Hyslop, C. (1998) Population status and recent trends in Canadian raptors: a review. Biol. Conserv. 83: 91-118.

Kostrzewa, A. (1996) A comparative study of nest-site occupancy and breeding performance as indicators for nesting-habitat quality in three European raptor species. Ethol. Ecol. Evol. 8: 1-18.

Krüger, O. (2002a). Analysis of nest occupancy and nest reproduction in two sympatric raptors: common buzzard Buteo buteo and goshawk Accipiter gentilis. Ecography 25: 523-532.

Krüger, O. (2002b) Interaction between common buzzard Buteo buteo and goshawk Accipiter gentilis: trade-offs revealed by a field experiment. Oikos 96: 441-452.

Krüger, O. and Lindström, J. (2001) Habitat heterogeneity affects population growth in goshawk Accipiter gentilis. J. Anim. Ecol. 70: 173-181.

Kuuluvainen, T., Tahvonen, O. and Aakala, T. (2012) Even-aged and uneven-aged forest management in boreal Fennoscandia: A review. Ambio 41: 720-737.

Linnell, J. D. C., Swenson, J. E. and Andersen, R. (2000) Conservation of biodiversity in Scandinavian boreal forests: large carnivores as flagships, umbrellas, indicators, or keystones? Biodiv. Conserv. 9: 857-868.

Lõhmus, A. (2005) Are timber harvesting and conservation of nest sites of forest-dwelling raptors always mutually exclusive? Anim. Conserv. 8: 443-450.

Maldonado, J., Sainz, H., Sánchez, R. and Xandri, P. (2001) Distribución y estado de conservación de los bosques españoles: un análisis de las carencias en la red de territorios protegidos. Pp. 101-117 in J. Camprodon and E. Plana, eds. Conservación de la biodiversidad y gestión forestal. Barcelona, Spain: Universitat de Barcelona.

MAMR (1995) IFN 2: http://www.magrama. gob.es/es/biodiversidad/servicios/bancodatos-naturaleza/informacion-disponible/ ifn2_descargas.aspx Last accessed:31/03/2013.

Manly, B. F. J., McDonald, L. L. and Thomas, D. L. (1993) Resource selection by animals. Statistical design and analysis for field studies. London, UK: Chapman and Hall.
Margalida, A., Moreno-Opo, R., Arroyo, B. E. and Arredondo, A. (2011) Reconciling the conservation of endangered species with economically important anthropogenic activities: interactions between cork exploitation and the cinereous vulture in Spain. Anim. Conserv. 14: 167-174.

Martin, J. L. and Joron, M. (2003). Nest predation in forest birds: influence of predator type and predator's habitat quality. Oikos 102: 641-653.

Martínez, J. E., Pagán, I. and Calvo, J. F. (2006) Factors influencing territorial occupancy and reproductive output in the booted eagle Hieraetus pennatus. Ibis 148: 807-819.

Martínez, J. E., Pagán, I., Palazón, J. A. and Calvo, J. F. (2007) Habitat use of booted Eagles (Hieraetus pennatus) in a special protection area: implications for conservation. Biodivers. Conserv. 16: 3481-3488.

Martí, R. and del Moral, J. C., eds. (2004) Atlas de las aves reproductoras de España. Madrid, Spain: Dirección General de Conservación de la Naturaleza and SEO/BirdLife.

Moreno-Opo, R., Fernández-Olalla, M., Margalida, A., Arredondo, A. and Guil, F. (2012) Effect of methodological and ecological approaches on heterogeneity of nestsite selection of a long-lived vulture. PLoS ONE 7: e33469.

Moreno-Rueda, G. and Pizarro, M. (2007) Snake species richness and shrubland correlate with the short-toed eagle distribution in southeastern Spain. Ann. Zool. Fenn. 44: 314-320.

Mortimer, M. J. (2008) Private property rights and selective private forest conservation: Could a Nordic policy address a United States problem? Environ. Manage. 41: 640-653.

Newburn, D., Reed, S., Berck, P. and Merenlender, A. (2005) Economics and land-use change in prioritizing private land conservation. Conserv. Biol. 19: 141138-15120.

Newton, I. (1979) Population ecology of raptors. Berkhamsted, UK: Poyser.

Penteriani, V. (2002) Goshawk nesting habitat in Europe and North America: a review. Ornis. Fenn. 79: 149-163. 
Penteriani, V. and Faivre, B. (2001) Effects of harvesting timber stands on goshawk nesting in two European areas. Biol. Conserv. 101: 211-216.

Perhans, K. Glöde, D., Gilbertsson, J., Persson, A. and Gustafsson, L. (2011) Fine-scale conservation planning outside of reserves: Cost-effective selection of retention patches at final harvest. Ecol. Econ. 70: $771-777$.

Petty, S. J. (1998) Ecology and conservation of raptors in forests. London, UK: Forestry Commission. (Forestry Commission Bulletin no. 118).

Poirazidis, K., Goutner, V., Tsachalidis, E. and Kati, V. (2007) Comparison of nestsite selection patterns of different sympatric raptor species as a tool for their conservation. Anim. Biodivers. Conserv. 30: 13138-1515.

Poirazidis, K., Schindler, S., Kati, V., Martinis, A., Kalivas, D. Kasimiadis, D., Wrbka, T. and Papageorgiu, A. C. (2011a) Conservation of biodiversity in managed forests: developing an adaptive decision support system. Pp. 380-399 in C. Li, R. Lafortezza, and J. Chen, eds. Landscape ecology and forest management: challenges and solutions in a changing globe. Beijing, China: Higher Education Press - Springer.

Poirazidis, K., Schindler, S., Kakalis, E., Ruiz, C., Bakaloudis, D. E., Scandolara, C., Eastham, C., Hristov, H. and Catsadorakis, G. (2011b) Population estimates for the diverse raptor assemblage of Dadia National Park, Greece. Ardeola 58: 3-17.

Prokop, P. (2004) The effect of nest usurpation on breeding success of the black-billed magpie Pica pica. Biologia 59: 213-217.

R Development Core Team (2009) R: A language and environment for statistical computing. Vienna, Austria: R Foundation for Statistical Computing.

Roberge, J-M and Angelstam, P. (2004) Usefulness of the umbrella species concept as a conservation tool. Conserv. Biol. 18: $76-85$.

Roth, T. and Weber, D. (2008) Top predators as indicators for species richness? Prey species are just as useful. J. Appl. Ecol. 45: 987-991.

Sánchez-Zapata, J. A. and Calvo, J. F. (1999) Raptor distribution in relation to landscape composition in semi-arid Mediterranean habitats. J. Appl. Ecol. 36: 254-262.

Santangeli, A., Lehtoranta, H. and Laaksonen, T. (2012) Successful voluntary conservation of raptor nests under intensive forestry pressure in a boreal landscape. Anim. Conserv. 15: $571-578$.

Seddon, P. J. and Leech, T. (2008) Conservation short cut, or long and winding road? A critique of umbrella species criteria Oryx 42: 240-245.

Selås, V. (1997) Nest-site selection by four sympatric forest raptors in southern Norway. J. Raptor Res. 31: 16-25.

Sergio, F., Newton, I., Marchesi, L. and Pedrini, P. (2006) Ecologically justified charisma: preservation of top predators delivers biodiversity conservation. J. Appl. Ecol. 43: 1049-1055.

Sergio, F., Caro, T., Brown, D., Clucas, B., Hunter, J., Ketchum, J., McHugh, K. and Hiraldo, F. (2008) Top predators as conservation tools: Ecological rationale, assumptions, and efficacy. Annu. Rev. Ecol. Evol. Syst. 39: 1-19.

Simberloff, D. (1998) Flagships, umbrellas, and keystones: is single-species management passé in the landscape era? Biol. Conserv. 83: 247-257.

Suárez, S., Balbotín, J. and Ferrer, M. (2000) Nesting habitat selection by booted eagles Hieraaetus pennatus and implication for management. J. Appl. Ecol. 37: 215-223.

Widén, P. (1997) How, and why, is the Goshawk (Accipiter gentilis) affected by modern forest management in Fennoscandia. J. Raptor Res. 31: 107-113.

Wikberg, S., Perhans, K., Kindstrand, C., Djupström, L. B., Boman, M., Mattsson, L., Schroeder, L. M., Weslien, J. and Gustafsson, L. (2009) Cost-effectiveness of conservation strategies implemented in boreal forests: The area selection process. Biol. Conserv. 142: 614-624.

Zuberogoitia, I., Martínez, J. E., Martínez, J. A., Zabala, J., Calvo, J. F., Castillo, I., Azkona, A., Iraeta, A. and Hidalgo, S. (2006) Influence of Management practices on nest site habitat selection, breeding and diet of the common buzzard Buteo buteo in two different areas of Spain. Ardeola 53: 83-98. 


\section{RAFAEL BARRIENTOS*}

Departamento de Ciencias Ambientales, Facultad de Ciencias del Medio Ambiente, Universidad de Castilla-La Mancha, Avenida Carlos III, s/n, E-45071, Toledo, Spain.

\section{BERNARDO ARROYO}

cl Paseo de la Florida, 28, E-280o8, Madrid, Spain.

*Author for correspondence; e-mail: rafael.barrientos@uclm.es

Received 7 August 2012; revision accepted 25 April 2013; Published online 29 October 2013 